\title{
New Pellet Feeds for Rabbits with a High Content of Nutrients and With the Addition of Dietary Supplements
}

\section{Alexander A. Shevtsov ${ }^{1}$, Alexey V. Drannikov², Alexander V. Vostroilov ${ }^{3}$, Elena E. Kurchaeva ${ }^{3}$, Anna A. Derkanosova ${ }^{4}$, and Alisa A. Torshina ${ }^{4}$}

${ }^{1}$ Military Educational and Scientific Center of the Air Force, Air Force Academy Named after Professor N.Ye. Zhukovsky and Yu.A. Gagarin

${ }^{2}$ Voronezh State University of Engineering Technologies, 19 Revolutioni Ave., Voronezh, 394036, Russia

${ }^{3}$ Voronezh State Agrarian University Named after Emperor Peter I, 1 Michurina St, Voronezh, 394087, Russia

${ }^{4}$ Voronezh State University of Engineering Technologies, 19 Revolutioni Ave., Voronezh, 394036, Russia

ORCID iDs: Alexander A. Shevtsov: 0000-0003-2599-5692; Alexey V. Drannikov: 0000-00023060-8688; Alexander V. Vostroilov: 0000-0003-1626-57352

Elena E. Kurchaeva: 0000-0001-5958-0909; Anna A. Derkanosova: 0000-0002-9726-9262

Alisa A. Torshina:0000-0003-3150-8686

Corresponding Author: Anna

Derkanosova.; email:

aa-derk@yandex.ru

\section{Dates}

Published 13 January 2022

Publishing services provided by

Knowledge E

(c) Alexander A. Shevtsov et

al. This article is distributed

under the terms of the

which permits unrestricted use and redistribution provided that the original author and source are credited.

Selection and Peer-review under the responsibility of the 8th Scientific and Practical Conference Conference Committee.
Abstract. This research presented the pellet feed production line. Three pellet feed formulasfor young stock rabbits (28-135 days old) were developed with the addition of experimental dietary supplements grouped into the following protein green complexes (PGC):PGC-92-1including the following supplements- dried herbal pulp from red clover, herbal alfalfa meal, and Sporotherminprobiotic; PGC-92-2 including the following supplements - protein feed concentrate from wheat stillage filtrate (syrup), herbal alfalfa meal, and Sporothermin probiotic; PGC-92-3 including the following supplements - PGC from red clover, herbal alfalfa meal,andSporothermin probiotic. These were compared with feed formulated without dietary supplements (PGC-92 (Control)). The nutritional value of the concentrate feeds met the requirements assigned for this group of animals. The storage of the formulatedconcentrate feeds took place in industrial conditions (the floor store) in paper bags of $30 \mathrm{~kg}$ per group at the temperature of $18-20{ }^{\circ} \mathrm{C}$ and the relative humidity of $65-70 \%$. Due to itsmoisture content exceeding the standard requirements, the check concentrate feed (Control) revealed a higher content of fungal and bacterial microflora. The fat acidityvalue and the total acidity increased, which indicated the instability of this batch of concentrate feed during storage. The experimental batches of concentrate feed had a stablequality and retained good quality throughout the testing period. The testing of the effects of the studied complexes in fattening young stock rabbits was carried out on the premises of the Lipetsk Rabbit LLC industrial complex with 2000 rabbits. The use ofall-in-onepellet feedsformulated with the addition ofdietary supplements made it possible to increase the slaughter yield by $3.62 \%, 4.45 \%$ and $3.96 \%$, while reducing feed intake per $1 \mathrm{~kg}$ of slaughter mass by $0.72 \mathrm{ECU}, 0.38 \mathrm{ECU}$ and $0.88 \mathrm{ECU}$. There was an increase in profit of 17725.25 rubles, 16114.38 rubles and 14168.55 rubles, and an increase in the level of profitability by $45.93 \%, 41.26 \%$ and $31.24 \%$, which resulted from a highersafety andgrowth performance of the raised rabbits.

Keywords: concentrate feeds, pellet feeds, dietary supplements, protein green complex, feed for rabbits, growth performance 


\section{Introduction}

One of the main issues in the development of the rabbit breeding industry is the organization of adequate feeding of individuals of different age groups [1, 7]. It is promising to use probiotic preparations in the composition of concentrate feeds for rabbits,contributing to the improvement of the physiological status of the fatted livestock, which is confirmed in the research work of the authors [2, 4-6].

Concentrate feeds are of great importance in the organization of scientifically grounded feeding of farm animals. Balanced in their basic nutritional composition, they provide theincrease in the productivity of animals by $10-12 \%$, while enriched with dietary supplements containing nutrients in a concentrated form, including crude protein and fibre, their efficiency increases by $25-30 \%$, which contributes, in turn,to the safety of the livestock, increasing their physiological status and growth performanceindicators [4].

Thedevelopeddietarysupplementswereusedintheformofconstituents for all-in-all pellet formulas for young stock rabbits (28-135 days old).

Thenutritional value of the developed pellet feeds meets the requirements assigned for this group of animals [3].

\section{Materials and Methods}

This research presents the pellet feedproduction line. Three pellet feed formulas for young stock rabbits (28-135 days old) have been developed with the addition of experimental dietary supplementswhich are grouped into the following protein green complexes (PGC): PGC-92-1 (258)including the following supplements - dried herbal pulp from red clover, herbal alfalfa meal, and Sporothermin probiotic; PGC-92-2 ( 259) including the following supplements - protein feed concentrate from wheat stillage filtrate (syrup), herbal alfalfa meal, and Sporothermin probiotic; PGC-92-3 (260) including the following supplements - PGC from red clover, herbal alfalfa meal, andSporothermin probiotic. The comparative analysis with the check feed formulatedwithout dietary supplements, PGC-92 (249)(Control), has been carried out. The nutritional value of the concentrate feedsmeets the requirements assigned for this group of animals.

\section{Results}

The formulas and the nutritional value of all-in-all pellet feeds are presented in Table 1. 


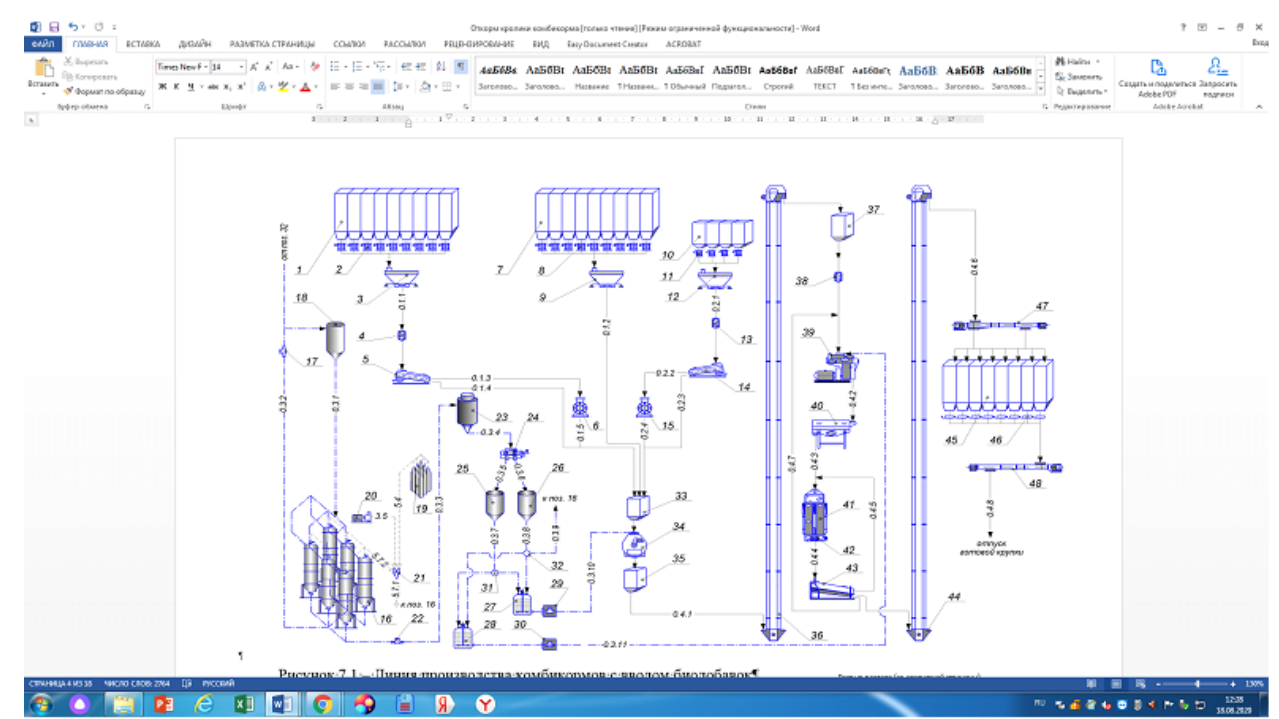

Figure 1: The pellet feeds production line with the addition of dietary supplements .

Figure1 shows a general view of the production line that implements the proposed method for the pellet feed production with the addition of dietary supplements based on clover, alcohol stillage and vitamin and mineral complexes with a high availability degree. Pelleting was carried out by means of themoist granulation technique. Moistening of loose (crumbled)concentrate feeds was carried out in theUZ-DSP-0.02 mixer. As a result, the pelletfeed with the moisture content of $16.8-20.4 \%$ was obtained, which was sent to theB6-DGV/1 pellet press.

Thepellet feedsproductionlineusing dietarysupplementsincludes the section forthe grain raw materials treatmentinvolvingcrushing, which has sequentially installed tanks 1 , equipped with auger feeders 2 , tank scales 3 , magnetic column 4 , single-screen sieving machine 5 and hammer crusher 6 ; the section for the grain raw materials treatmentnot involvingcrushing, which has sequentially installed tanks 7 , equipped with screw feeders 8 , and tank scales 9; the section for the preparation of protein and mineral raw materials, which has sequentially installed tanks 10 , equipped with screw feeders 11 , tank scales 12, magnetic column 13, single-screen sieving machine 14 and hammer crusher 15; the molasses preparation section 16 withthe circulation pump 17, the storage bin for molasses 18 , the battery of carbon dioxide cylinders 19 , the compressor 20 , the gas mixer 21 and the pump 22 providingthe molasses feed to the centrifugation section, which hassequentially installed the tempering tank 23 and the centrifuge 24 after which parallelly installedtanks 25 and 26, the agitator 27 and the agitator 28 , the dosing pumps 29 and 30 , providing molasses dosing, the two-flow distributor 31 and the three-flow distributor 32; the section for loose(crumbled)concentrate feed production, including the over-mixertank 33 , the batch mixer with the block of nozzles 
TABLE 1: The formulas and the nutritional value of pilot batches of pellet feeds.

\begin{tabular}{|c|c|c|c|c|c|c|c|c|}
\hline \multirow[t]{3}{*}{ Composition } & \multicolumn{8}{|c|}{ Content in the formula, \% } \\
\hline & \multicolumn{2}{|c|}{ PGC-92 (Control) } & \multicolumn{2}{|c|}{ PGC-92-1 } & \multicolumn{2}{|c|}{ PGC-92-2 } & \multicolumn{2}{|c|}{ PGC-92-3 } \\
\hline & In the formula & Quantity, kg/t & In the formula & Quantity, kg/t & In the formula & Quantity, kg/t & In the formula & Quantity, kg/ \\
\hline 1 & 2 & 3 & 4 & 5 & 6 & 4 & 8 & 9 \\
\hline Wheat & 6,00 & 60,000 & 6,00 & 60,000 & 6,00 & 60,000 & 6,00 & 60,000 \\
\hline Barley & 7,90 & 79,000 & 7,90 & 79,000 & 7,90 & 79,000 & 7,90 & 79,000 \\
\hline Molasses & 2,00 & 20,000 & 2,00 & 20,000 & 2,00 & 20,000 & 2,00 & 20,000 \\
\hline Oats & 8,00 & 80,000 & 17,60 & 176,000 & 17,60 & 176,000 & 17,60 & 176,000 \\
\hline Corn & 10,00 & 100,000 & - & & - & & - & \\
\hline $\begin{array}{l}\text { Wheat bran } \\
\text { пшеничные }\end{array}$ & 15,00 & 150,000 & 15,00 & 150,000 & 15,00 & 150,000 & 15,00 & 150,000 \\
\hline $\begin{array}{l}\text { Driedherbalpulp } \\
\text { from red clover }\end{array}$ & - & - & 15,00 & 150,000 & - & - & - & \\
\hline Sunflower cake & 16,50 & 165,000 & 16,50 & 165,000 & 16,50 & 165,000 & 16,50 & 165,000 \\
\hline $\begin{array}{l}\text { PGC from red } \\
\text { clover }\end{array}$ & - & & - & - & - & & 4,00 & 40,000 \\
\hline Sunflower meal & 8,00 & 80,000 & 8,00 & 80,000 & 8,00 & 80,000 & 4,00 & 40,000 \\
\hline $\begin{array}{l}\text { Herbal alfalfa } \\
\text { meal }\end{array}$ & 20,0 & 200,000 & 5,00 & 50,000 & 10,00 & 100,000 & 20,00 & 200,000 \\
\hline Meat meal & 3,00 & 30,000 & 3,00 & 30,000 & 3,00 & 30,000 & 3,00 & 30,000 \\
\hline $\begin{array}{lr}\text { Protein feed } \\
\text { concentrate from } \\
\text { wheat stillage } \\
\text { filtrate }\end{array}$ & - & - & - & & 10,00 & 100,000 & - & \\
\hline Common salt & 0,20 & 2,000 & 0,10 & 1,000 & 0,10 & 1,000 & 0,10 & 1,000 \\
\hline Defluorinated phos & 1,40 & 14,000 & 1,40 & 14,000 & 1,40 & 14,000 & 1,40 & 14,000 \\
\hline Fodder chalk & 1,00 & 10,000 & 1,40 & 14,000 & 1,40 & 14,000 & 1,40 & 14,000 \\
\hline Sporothermin & - & - & 0,10 & 1,000 & 0,10 & 1,000 & 0,10 & 1,000 \\
\hline $\begin{array}{l}\text { CVPП90- } \\
1 \text { Kwiththe } \\
\text { addition of feed } \\
\text { supplement } \\
\text { of enzyme } \\
\text { sorption action } \\
\text { and sorbed- } \\
\text { cholinechloride } \\
\text { supplement }\end{array}$ & 1,00 & 10,000 & 1,00 & 10,000 & 1,00 & 10,000 & 1,00 & 10,000 \\
\hline \multicolumn{9}{|l|}{ Qualityindicators(\%) } \\
\hline $\begin{array}{l}\text { EFU (Energtic } \\
\text { feed unit) }\end{array}$ & 1,09 & & \multicolumn{2}{|c|}{1,14} & \multicolumn{2}{|c|}{1,18} & \multicolumn{2}{|c|}{1,11} \\
\hline $\begin{array}{l}\text { Metabolic energy, } \\
\text { MJ }\end{array}$ & 10,96 & & \multicolumn{2}{|c|}{11,42} & \multicolumn{2}{|c|}{11,85} & \multicolumn{2}{|c|}{11,13} \\
\hline Crude protein & 18,46 & & \multicolumn{2}{|c|}{19,16} & \multicolumn{2}{|c|}{19,78} & \multicolumn{2}{|c|}{18,53} \\
\hline Crude fibre & 11,83 & & \multicolumn{2}{|c|}{12,32} & \multicolumn{2}{|c|}{11,89} & \multicolumn{2}{|c|}{12,11} \\
\hline Lysine & 0,68 & & \multicolumn{2}{|c|}{0,73} & \multicolumn{2}{|c|}{0,72} & \multicolumn{2}{|c|}{0,72} \\
\hline Methionine+Cystin & $\in 0,67$ & & \multicolumn{2}{|c|}{0,70} & \multicolumn{2}{|c|}{0,73} & \multicolumn{2}{|c|}{0,67} \\
\hline Threonine & 0,64 & & \multicolumn{2}{|c|}{0,67} & \multicolumn{2}{|c|}{0,68} & \multicolumn{2}{|c|}{0,65} \\
\hline $\mathrm{Ca}$ & 1,41 & & \multicolumn{2}{|c|}{1,54} & 1, & 41 & & 59 \\
\hline $\mathrm{P}$ & 0,78 & & 0,7 & & 0 , & ,81 & & ,76 \\
\hline
\end{tabular}


TABLE 2: Qualityindicatorsof pellet feeds

\begin{tabular}{|c|c|c|c|c|c|c|c|c|}
\hline \multirow{3}{*}{$\begin{array}{l}\text { Type } \\
\text { pelletfeed }\end{array}$} & \multicolumn{8}{|c|}{ Qualityindicators } \\
\hline & \multicolumn{3}{|c|}{ After the pellet press } & \multicolumn{5}{|c|}{ After cooler } \\
\hline & $\begin{array}{l}\text { Moisture, } \\
\%\end{array}$ & $\begin{array}{l}\text { Temperature, } \\
{ }^{\circ} \mathrm{C}\end{array}$ & $\begin{array}{l}\text { Crumble } \\
\text { occurrence, } \\
\%\end{array}$ & Moisture, \% & $\begin{array}{l}\text { Crumbling } \\
\text { ability, \% }\end{array}$ & $\begin{array}{l}\text { Crumble } \\
\text { occur- } \\
\text { rence, } \\
\%\end{array}$ & $\begin{array}{l}\text { Average } \\
\text { pellet } \\
\text { granule } \\
\text { length, MM }\end{array}$ & $\begin{array}{l}\text { Bulk weight } \\
\mathrm{K} \Gamma / \mathrm{M}^{3}\end{array}$ \\
\hline $\begin{array}{lr}\text { Formula } & 1 \\
\text { (контроль) } & 249\end{array}$ & 17,2 & 53 & 13,4 & 14,2 & 9,5 & 10,0 & 9,8 & 586 \\
\hline Formula2 258 & 18,6 & 52 & 7,6 & 14,0 & 8,4 & 8,2 & 10,3 & 606 \\
\hline Formula3 259 & 19,3 & 53 & 6,7 & 13,9 & 7,7 & 7,4 & 10,0 & 617 \\
\hline Formula4 260 & 19,5 & 53 & 6,2 & 14,0 & 7,5 & 7,8 & 10,0 & 619 \\
\hline
\end{tabular}

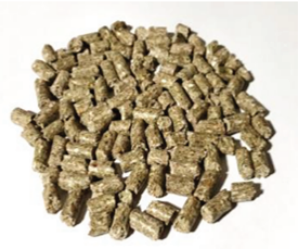

PelletfeedPGC-92

(Control)

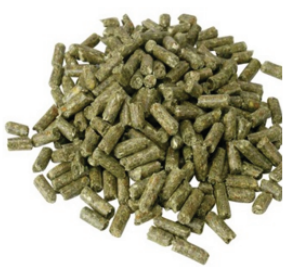

PelletfeedPGC-92 -1

PelletfeedPGC-92 -2
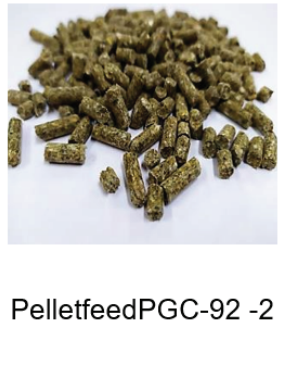

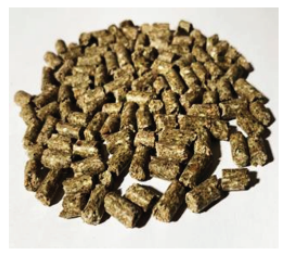

Pelletfeed

PGC-92 -3

Figure 2: Pelletfeedswiththe addition of dietay supplements foryoungstockrabbits.

for molasses addition34, under-mixertank 35; the section for pellet production, including the sequentially installed elevator 36 , the over-pelletertank 37 , the magnetic column 38 , the pellet press 39 , the vibrating dryer 40 , the cooling column 41 , thecrusher 42 and the two-screen sifting machine 43 , after which the elevator 44 and the storage tanks for the finished product 45 , equipped with screw feeders 46 and scraper conveyors 47 , 48.

The finished pellet feed is fed to the consumer from storage tanks 45 along the line 0.4.8.

The quality indicators of pellet feeds are presented in Table. 2. The developed pellet samples are shown in Figure 2. The resulting concentrate feed formulated with the addition of dietary supplementsmeets the requirements of GOST 32897-2014.

The storage of the producedpelletfeedstook place in industrial conditions (the floor store) in paper bags of $30 \mathrm{~kg}$ per group at the temperature of $18-20^{\circ} \mathrm{C}$ and the relative humidity of $65-70 \%$. The change in the quality indicators of pelletfeeds is presented in Table 3.

Due to the moisture content exceeding the standard requirements the checkpelletfeed (Control) revealed a higher content of fungal and bacterial microflora. The fat acidityvalue and the total acidity increased, which indicates the instability of this batch of 
TABLE 3: The change in the quality indicators of the developedpelletfeedsduring the storage.

\begin{tabular}{|c|c|c|c|c|c|c|c|c|}
\hline \multirow[t]{4}{*}{ Indicators } & \multicolumn{8}{|c|}{ Pellet feed formula } \\
\hline & \multicolumn{2}{|c|}{ PGC-92 (Control) } & \multicolumn{2}{|r|}{ PGC-92-1 } & \multicolumn{2}{|c|}{ PGC-92-2 } & \multicolumn{2}{|c|}{ PGC-92-3 } \\
\hline & \multicolumn{8}{|c|}{ Storage time, months } \\
\hline & 0 & 2 & 0 & 2 & 0 & 2 & 0 & 2 \\
\hline $\begin{array}{l}\text { Moisture con- } \\
\text { tent, } \%\end{array}$ & 14,2 & 15,6 & 14,0 & 13,5 & 13,9 & 14,2 & 14,0 & 14,3 \\
\hline $\begin{array}{l}\text { Total acidity, } \\
{ }^{\circ} \mathrm{N}\end{array}$ & 4,1 & 4,9 & 4,2 & 4,6 & 4,3 & 4,7 & 4,1 & 4,6 \\
\hline $\begin{array}{l}\text { Microfungus, } \\
10^{3} \mathrm{CFU} / \mathrm{g}\end{array}$ & 2,7 & 3,8 & 2,8 & 2,8 & 2,7 & 2,8 & 2,8 & 3,0 \\
\hline $\begin{array}{l}\text { Total bacterial } \\
\text { number, } \\
10^{5} \mathrm{CFU} / \mathrm{g}\end{array}$ & 1,6 & 2,9 & 1,7 & 1,7 & 1,7 & 1,8 & 1,7 & 1,9 \\
\hline $\begin{array}{l}\text { Fat acidity } \\
\text { value, } \\
\mathrm{mgKOH} / \mathrm{g}\end{array}$ & 33,0 & 46,7 & 34,0 & 36,4 & 31,3 & 34,6 & 35,0 & 36,9 \\
\hline $\begin{array}{l}\text { Fat peroxide } \\
\text { value, } \% \mathrm{~J}\end{array}$ & 0,12 & 0,16 & 0,13 & 0,13 & 0,13 & 0,14 & 0,13 & 0,15 \\
\hline
\end{tabular}

pelletfeed during storage. The experimental batches of pelletfeeds formulatedwith the addition of dietary supplements of vegetable origin and mineral enrichers had stable keeping quality and retained good quality throughout the testing period.

The results of the production testing of the effects of the studied complexes at fattening young stock rabbits on the premises of the Lipetsk Rabbit LLC industrial complex are presented in Table 4.

The use ofall-in-onepellet feedsformulated with the addition ofdietary supplements made it possible to increase the slaughter yield by $3.62,4.45$ and $3.96 \%$, while reducing feed intake per $1 \mathrm{~kg}$ of slaughter mass by $0.72,0.38$ and $0.88 \mathrm{ECU}$. The increase in profit by $17725.25,16114.38$ and 14168.55 rubles, as well as the level of profitability by $45.93,41.26$ and $31.24 \%$ was achieved, which results from a higher safety and growth performance of the raised livestock of rabbits.

\section{Discussion}

Thus, the use of fortified pelletfeeds in the diets for rabbits contributes to the improvement of the physiological status of rabbits and the increase in growth performanceindicators, and also positively affects the digestion processes and the safety of the fattened young stock. The analysis of the chemical composition of meat obtained from rabbits of the control and experimental groups showed that the dietary supplements use promotes the accumulation of protein substances in the muscle tissues, which provides 
TABLE 4: The results of the production testing.

\begin{tabular}{|c|c|c|c|c|}
\hline \multirow[t]{2}{*}{ Indicator } & \multicolumn{4}{|c|}{ Group } \\
\hline & Group1 & Group2 & Group3 & Group4 \\
\hline $\begin{array}{l}\text { Number of rabbits at setting up the test, } \\
\text { heads }\end{array}$ & 100 & 100 & 100 & 100 \\
\hline $\begin{array}{l}\text { Number of rabbits at taking testing results, } \\
\text { heads }\end{array}$ & 75 & 97 & 98 & 100 \\
\hline \multicolumn{5}{|l|}{ Live weight of all livestock, kg: } \\
\hline - when setting up for testing & 128,50 & 128,4 & 129,50 & 128,00 \\
\hline - when taking testing results & 233,22 & 337,30 & 332,22 & 353,90 \\
\hline Slaughter yield, \% & 49,90 & 53,52 & 54,35 & 53,86 \\
\hline Weight of one carcass, $\mathrm{g}$ & 1,48 & 1,73 & 1,69 & 1,73 \\
\hline Additional gain in live weight, $\mathrm{kg}$ & 104,72 & 208,90 & 202,72 & 225,90 \\
\hline Costofadditionalgain, rub. & 6756,17 & 10986,09 & 11039,83 & 14677,50 \\
\hline $\begin{array}{l}\text { EFU costs for an increase in } 1 \mathrm{~kg} \text { of live } \\
\text { weight, } \mathrm{kg}\end{array}$ & 3,04 & 2,85 & 3,02 & 2,73 \\
\hline EFUcosts per $1 \mathrm{~kg}$ of slaughter weight, $\mathrm{kg}$ & 6,45 & 5,73 & 6,07 & 5,57 \\
\hline Meat yield, kg & 100,50 & 154,23 & 150,92 & 158,70 \\
\hline Cost of $1 \mathrm{~kg}$ of concentrate feeds, rub. & 23,06 & 21,02 & 21,22 & 26,43 \\
\hline Nutritional value of concentrate feeds, EFU & 1,09 & 1,14 & 1,18 & 1,11 \\
\hline $\begin{array}{l}\text { Feed consumption for the entire gain in live } \\
\text { weight,EFU }\end{array}$ & 711,22 & 962,04 & 1006,07 & 965,70 \\
\hline Costofmaintainingfixedassets, rub. & 20400 & 20400 & 20400 & 20400 \\
\hline Costs for concentrate feeds, rub. & 15046,65 & 17738,78 & 18092,17 & 22994,10 \\
\hline Raising cost total, rub. & 35446,65 & 38138,80 & 38492,17 & 43394,10 \\
\hline Realizable value of $1 \mathrm{~kg}$ of meat, rub. & 380,00 & 380,00 & 380,00 & 380,00 \\
\hline Proceeds from the sale of meat, rub. & 38190,00 & 58607,40 & 57349,90 & 60306,00 \\
\hline Profit, rub. & 2743,35 & 20468,60 & 18857,73 & 16911,90 \\
\hline Profitability level, \% & 7,73 & 53,66 & 48,99 & 38,97 \\
\hline
\end{tabular}

opportunities for the introduction of these feedingrations into industrial rabbit breeding [8-15] in order to obtain the finished product that meets the safety and environmental requirements.

\section{References}

[1] Amaravadhi SC, Mallam M, Manthani GP, Komireddy KR. Effect of dietary supplementation of probiotics and enzymes on the haematology of rabbits reared under two housing systems. Veterinary World. 2012;5(12):748-753.

[2] Kutin DD. Influence of the feeding regime on the rabbits' body. International Journal of Applied Sciences and Technologies Integral. 2018;4:181-186. 
[3] Standartinform M. GOST 32897-2014. Concentrate feed for fur-bearing animals, rabbits and nutria. General technical conditions. Moscow: Standartinform; 2015.

[4] Kurchaeva EE, Vostroilov AV, Artemov ES, Maksimov IV. Conference on Innovations in Agricultural and Rural development; 2019. 341 IOP Publishing. Improving the productivity of rabbits through the sharing of probiotic complexes and herbal supplements. March $4^{\text {th }}$, Russia, Voronezh.

[5] Yurina NA, Pskhatsieva ZV, Kononenko SI, Esaulenko NN, Erokhin VV. Efficiency of the use of feed supplements Sporothermin and Kovelos in concentrate feeds. Actual Problems of Intensive Development of Livestocking. 2014;17(1):185-192.

[6] Shentsova ES, Vostroilov AV, Lytkina LI, Kurchaeva EE. Improvement of the physiological status and quality of rabbit meat against the background of the use of the probiotic complex "SPOROTERMIN" in the composition of concentrate feeds. Bulletin of Voronezh State University of Engineering Technologies. 2019;81(3):57-63.

[7] Kalashnikov AP, Fisinin VI, Shcheglov VV, Kleymenov NI.Feeding regimes and rations for farm animals. Moscow. Rosselkhozakademiya. 2003.

[8] Bhatt RS, Agrawal AR, Sahoo A. Effect of probiotic supplementation on growth performance, nutrient utilization and carcass characteristics of growing chinchilla rabbits. Journal of Applied Animal Research. 2017;45(1):304-309.

[9] Birolo M, Trocino A, Tazzoli M, Xiccato G. Effect of feed restriction and feeding plans on performance, slaughter traits and body composition of growing rabbits. World Rabbit Science. 2017;25:113-122.

[10] Bogdanova OV, Alekseeva LV, Lukyanov AA. Biologically active substance application efficiency for meat rabbit breeding. EurAsian Journal of BioSciences. 2018;12(2):431-435.

[11] Zhu F. Triticale: Nutritional composition and food uses. Food Chemistry. 2018;241:468-479.

[12] Ndagijimana P., Xuejiao L., Zhiwei L., Guang-Wei Yu., Yin W. Optimized synthesis of a core-shell structure activated carbon and its adsorption performance for Bisphenol A. Science of the Total Environment. 2019;689:457-468.

[13] Villamide M.J., García J., Cervera C. et al. Comparison among methods of nutritional evaluation of dietary ingredients for rabbits. Animal Feed Science and Technology.2003;109(1-4):195-207.

[14] Yang W., Benchaar C., Ametaj B., Beauchemin K. Dose response to eugenol supplementation in growing beef cattle: Ruminal fermentation and intestinal digestion. Animal Feed Science and Technology.2010;158:57-64. 
[15] Alferov AS, Bakhchevnikov ON, Braginets SV, Chernutsky MV. Development of energy-saving technology for introducing the plant mass of forage grasses into the composition of concentrate feeds. Bulletin of the NSEEU. 2017;10(77):71-80. 